\title{
STATISTICAL OPTIMIZATION OF ADSORPTION VARIABLES FOR BIOSORPTION OF CHROMIUM (VI) USING CRUDE TAMARIND POD SHELL AND ACTIVATED CARBON
}

\author{
Sudhanva.M.Desai ${ }^{1}$, N.C.L.N Charyulu ${ }^{2}$, Satyanarayana V Suggala ${ }^{3}$ \\ ${ }^{1}$ Associate Professor, Department of Chemical Engineering, Dayananda Sagar College of Engineering, Bangalore, \\ India \\ ${ }^{2}$ Professor, Department of Chemical Engineering, C.B.I.T. Hyderabad, India. \\ ${ }^{3}$ Professor Department of Chemical Engineering, J.N.T.U.A.C.E Anantapuramu, India.
}

\begin{abstract}
Hexavalent Chromium is a major pollutant released during several industrial operations. In this study low-cost agro waste biosorbent tamarind (Tamarindus indica) pod shells with partial and complete Pyrolysed forms were explored for the removal of hexavalent chromium ions from aqueous solution. All the biosorption experiments were carried out in batch mode to optimize process parameters using response surface methodology. Based on central composite design, quadratic model was developed to correlate the variables to the response. Statistical analysis was carried out to identify the most influential factor for all the adsorbents. Through analysis of variance (ANOVA) it was observed that $\mathrm{pH}$ is significant for crude and temperature is significant for pyrolysed adsorbent. Among all the adsorbents tested, crude tamarind, removed a maximum of $96.09 \%$ of chromium with biomass loading of $4.59 \mathrm{~g} / 100 \mathrm{ml}$ at the optimized conditions of initial concentration $71.7213 \mathrm{mg} / \mathrm{l}$, pH 2.47, and temperature of $41.82^{\circ} \mathrm{C}$.
\end{abstract}

Keywords: Biosorption, Tamarindus indica, Hexavalent chromium, Pyrolysis, ANOVA

\section{INTRODUCTION}

In aqueous system chromium exists in two oxidation states trivalent chromium [Cr (III)]. and hexavalent chromium [Cr (VI)]. Both oxidation states of chromium have different chemical, biological and environmental characteristics [1]. $\mathrm{Cr}$ (III) is relatively insoluble and required by microorganisms in small quantities as an essential trace metal nutrient [2], while Chromium [Cr (VI)]. is a great concern because of its toxicity. Chromium (in this text hereafter chromium refers to $\mathrm{Cr}(\mathrm{VI})$ ) has been reported to be a primary contaminant to humans, animals, plants and microorganisms and it is known to be carcinogenic [3-5].

Chromium is used in a variety of industrial applications hence, large quantities of chromium is discharged into the water bodies. Water bodies and ground water are polluted by chromium by the waste coming out of electroplating fabrication, paints and pigments, mining, leather tanning, etc. [6-8]. Due to environmental concern, discharge limits of chromium have been closely monitored by most industrial countries. Chromium concentration in industrial waste water ranges from 0.5 to $270 \mathrm{mg} / 1$ [7]. The tolerance limit for chromium for discharge into inland surface waters is 0.1 $\mathrm{mg} / \mathrm{l}$ and in potable water is $0.05 \mathrm{mg} / \mathrm{l}[9,10]$. In order to comply with this limit, it is essential that industries treat their effluents to reduce the chromium concentration in water and wastewater to acceptable levels before its transport and cycling into the natural environment.
Appropriate technologies are applied to reduce the level of chromium in final effluents. In wastewater treatment, various methods utilized to remove chromium include reduction followed by chemical precipitation [11], ion exchange [12], electrochemical precipitation [13], reduction [14], adsorption [15], solvent extraction [16], membrane separation [17], concentration [18], evaporation and reverse osmosis [19, 20].

Above all adsorption is by far most versatile and effective method for removing any contaminants like heavy metal, especially, if combined with appropriate regeneration steps. This solves the problem of sludge disposal and renders the system more economically viable, especially if low cost adsorbents are used [21]. In the last few years, several approaches have been reported in this direction utilizing inexpensive and effective adsorbent for removal of chromium from aqueous solutions. Many biosorbent were tried for chromium removal as seen in literature [22-37]. The materials tried for this purpose range from industrial wastes to agricultural waste products and biomass. Some examples are hydrous concrete particles[22], paper mill sludge [16], seaweed biosorbent [23], sugar beet pulp[24], wheat bran [25], activated groundnut husk carbon[26], coconut husk and palm pressed fibers [27], coconut shell, wood and dust coal activated carbons [28], coconut tree sawdust carbon [29], used tyres carbon [30], cactus, wool, charcoal, and pine needles [31], rice husk carbon [32], hazelnut shell carbon [33,34], almond shell carbon [35], corncob [36]. and cow dung carbon[37]. 
Agro waste such as tamarind pod shell as biosorbent is promising because of low cost, abundance in availability in India and reasonably high efficiency. It will not be used for any other purpose other than as low grade fuel. In this study tamarind pod shell, partially pyrolysed tamarind pod shell and completely pyrolysed tamarind pod shell were used for chromium removal.

Response Surface Methodology (RSM) is a collection of statistical technique for design of experiments, model building, evaluation of the effects of parameters and optimizing the parameters for maximum removal efficiency. It is widely used for multivariable studies in many processes [38-40]. No work has been carried out with partial and complete pyrolysis of tamarind pod shell. The objective of present study is to quantify the biosorption of chromium by various forms of tamarind pod shell and to select the best out of them. Further, to optimize the process parameters for maximum uptake of chromium using RSM.

\section{MATERIALS AND METHODS}

\subsection{Preparation of Biosorbent}

\subsubsection{Collection of Tamarind Pod Shells}

Natural agro waste biosorbent Tamarindus indica pod shells collected from Kolar district, Karnataka were used for removal of chromium. Natural biosorbent along with various pyrolysis processes were employed for comparative metal removal efficiency.

\subsubsection{Crude (Untreated) Tamarind Pod Shells (T)}

Tamarind pod shells were sun dried, powdered, sieved using 60/80 mesh BSS Standard sieve to get uniform sized particles. The fraction that was retained on 80 mesh were collected, washed thoroughly with distilled water and dried in the hot air oven for 2 hours at $80^{\circ} \mathrm{C}$.

\subsubsection{Preparation of Activated Carbon by Pyrolysis}

The activated carbons used in this study were prepared by Complete Pyrolysis and Partial Pyrolysis using Crude Tamarind pod shell in a muffle furnace. The complete pyrolysis tamarind (TCP) adsorbent is obtained by just keeping the crucible in the muffle furnace whereas partial pyrolysed tamarind (TPP) is obtained by keeping the lid on the crucible.

\subsection{Preparation of Chromium Stock Solution}

Synthetic chromium solution was prepared by dissolving potassium dichromate $\left(\mathrm{K}_{2} \mathrm{Cr}_{2} \mathrm{O}_{7}\right)$ in double distilled water. $1000 \mathrm{ppm}$ of stock chromium solution was prepared by dissolving $2.83 \mathrm{mg}$ of potassium dichromate in one litre of double distilled water. Other required concentrations were prepared by diluting the stock solution. The $\mathrm{pH}$ of the solution was adjusted to the required value.

\subsubsection{Preparation of Diphenylcarbazide (DPC)}

\section{Solution}

Diphenylcarbazide (DPC) solution was prepared by dissolving $250 \mathrm{mg}$ of DPC in $50 \mathrm{ml}$ of acetone in a $100 \mathrm{ml}$ volumetric flask.

\subsection{Analysis of Chromium}

$0.25 \mathrm{ml}$ of phosphoric acid was added to $1 \mathrm{ml}$ of standard sample containing known concentration of chromium, $\mathrm{pH}$ was adjusted to $1.0 \pm 0.3$ using $0.2 \mathrm{~N}$ sulphuric acid. The solution was mixed well and then diluted to $100 \mathrm{ml}$ in a volumetric flask using double distilled water. Further $2 \mathrm{ml}$ of DPC solution was added and mixed well. After full colour development for $10 \mathrm{~min}, 4 \mathrm{ml}$ of this solution was used in an absorption cell and the concentrations were measured spectrometrically at $540 \mathrm{~nm}$ in UV-double beam spectrophotometer [Shimadzu- UV Visible 1700]. The calibration curve is prepared by measuring the absorbance of different known concentrations of chromium solutions and plotting a graph between concentrations versus absorbance. A straight line is obtained with $\mathrm{R}^{2}$ of 0.994 .

\subsection{Initial Experiments}

The initial experiments were conducted to fix limits of the parameters to be varied. Maximum chromium removal is observed with the range of initial metal ion concentrations of $10-200 \mathrm{ppm}, \mathrm{pH} 1-7$, temperature $30-50^{\circ} \mathrm{C}$ and biosorbent dosage of $1-10 \mathrm{~g} / 100 \mathrm{ml}$. These ranges of variables were employed for further study.

\subsection{Design of Experiments using Central Composite Design (CCD) [42]}

The parameters initial metal ion concentration, $\mathrm{pH}$, temperature and biosorbent dosage were chosen as independent variables and the removal efficiency of chromium is output response. A $2^{4}$ full factorial experimental design, with seven replicates at the centre point and thus a total of 31 experiments were employed in this study using the statistical software, MINITAB 16 (PA, USA). The centre point replicates were chosen to verify any change in the estimation procedure as a measure of precision property. Each independent variable had 5 levels which were $-2,-1,0,+1$ and +2 . Therefore, a total of 31 different combinations were chosen in random order according to a CCD configuration for four factors. Table. 1 shows the levels of chosen variables used in the experiment for the removal of chromium.

The analysis focused on how the removal efficiency is influenced by independent variables, metal concentration $\left(\mathrm{X}_{1}\right), \mathrm{pH}\left(\mathrm{X}_{2}\right)$, temperature $\left(\mathrm{X}_{3}\right)$ and biosorbent dosage $\left(\mathrm{X}_{4}\right)$. The dependent output variable is maximum removal efficiency (Y). 


\subsection{Response Surface Methodology (RSM)}

Response surface methodology is an empirical statistical technique employed for multiple regression analysis by using quantitative data obtained from properly designed experiments to solve multivariate equations simultaneously. The experiments with different metal ion concentration, $\mathrm{pH}$, temperature and adsorbent dosage were employed simultaneously covering the spectrum of variables for the removal of chromium in CCD.

Table 1: Central composite design for biosorption of chromium

\begin{tabular}{|l|l|l|l|l|l|}
\hline \multirow{2}{*}{$\begin{array}{l}\text { Independent } \\
\text { variable }\end{array}$} & \multicolumn{5}{|l}{ Range and Level } \\
\cline { 2 - 6 } & $\mathbf{- 2}$ & $\mathbf{- 1}$ & $\mathbf{0}$ & $\mathbf{+ 1}$ & $\mathbf{+ 2}$ \\
\hline$\left(\mathbf{X}_{\mathbf{1}}\right)$ & 50 & 87.5 & 125 & 162.5 & 200 \\
\hline$\left(\mathbf{X}_{\mathbf{2}}\right)$ & 1 & 2.5 & 4.0 & 5.5 & 7 \\
\hline$\left(\mathbf{X}_{\mathbf{3}}\right)$ & 30 & 35 & 40 & 45 & 50 \\
\hline$\left(\mathbf{X}_{\mathbf{4}}\right)$ & 1 & 3.25 & 5.5 & 7.75 & 10 \\
\hline
\end{tabular}

Where

$\left(\mathrm{X}_{1}\right)$ is Initial Chromium ion concentration (ppm)

$\left(\mathrm{X}_{2}\right)$ is $\mathrm{pH}$

$\left(\mathrm{X}_{3}\right)$ is Temperature $\left({ }^{\circ} \mathrm{C}\right)$

$\left(\mathrm{X}_{4}\right)$ is Biomass loading $(\mathrm{g} / 100 \mathrm{ml})$

The regression analysis was performed to estimate the response function as a second order polynomial as shown in equation 1

\section{$Y=\beta_{0}+\beta_{1} X_{1}+\beta_{2} X_{2}+\beta_{3} X_{3}+\beta_{4} X_{4}+\beta_{11} X_{1}{ }^{2}+\beta_{22} X_{2}{ }^{2}+\beta_{33} X$ $3^{2+\beta_{44}} X_{4}{ }^{2+\beta_{12}} X_{1} X_{2}+\beta_{13} \quad X_{1} X_{3}+\beta_{14} X_{1} X_{4}+\beta_{23} X_{2}$ $\mathbf{X}_{3}+\boldsymbol{\beta}_{24} X_{2} X_{4}+\beta_{34} X_{3} X_{4}$

$X_{1}, X_{2}, X_{3}, X_{4}$ are linear effects, $X_{1}^{2}, X_{2}^{2}, X_{3}^{2}, X_{4}^{2}$ are squared effects, $X_{1} X_{2}, X_{1} X_{3}, X_{1} X_{4}, X_{2} X_{3}, X_{2} X_{4}, X_{3} X_{4}$ are interaction effects and $Y$ is the predicted response. $\beta_{0}$ is constant coefficient, $\beta_{1}, \beta_{2}, \beta_{3}, \beta_{4}$ are linear coefficients, $\beta_{11,} \beta_{22}, \beta_{33}, \beta_{44}$ are squared coefficients, and $\beta_{12,}, \beta_{13}, \beta_{14}, \beta_{23}, \beta_{24}, \beta_{34}$ are interactive coefficients, respectively.

A statistical software package Minitab 16, was used for regression analysis of the data obtained and to estimate the coefficient of the regression equation. The equations were validated by the statistical test called ANOVA. The significance of each term in the equation is to estimate the goodness of fit in each case. Response surface were drawn to determine the individual, square and interactive effects of test variable on percentage removal of chromium.

\subsection{Batch Experiments}

Batch adsorption studies were performed by Shaking $100 \mathrm{ml}$ of different solutions in $250 \mathrm{ml}$ conical flasks with cork lid in constant temperature shaker at the conditioned mentioned by central composite design to obtain the equilibrium data.
All experiments were performed in triplicate and the results were averaged. After specified time interval, the samples were analysed by the spectrophotometric method.

\subsection{Optimization of Parameters}

The second degree polynomial equation is solved and the optimum values for the variables are obtained using response optimizer in Minitab 16.

\section{RESULTS AND DISCUSSIONS}

\subsection{Central Composite Design (CCD) Analysis}

The results of experiments performed according to the CCD design are given in Table 2. Table 2 gives the experimental results along with the predicted values (section 3.2) for all three adsorbents T, TCP and TPP.

It may be observed from Table 2 that the percentage removal is higher at lower $\mathrm{pH}$. In acidic $\mathrm{pH}$, the biosorbent surface may be protonated and hence the positively charged biosorbent removes higher amounts of Chromium in the anionic form $\mathrm{HCrO}_{4}^{-}$. With the increase in the $\mathrm{pH}$ of the system, the degree of protonation on the surface reduces gradually and hence at higher $\mathrm{pH}$, above 3.0, other mechanism like physical adsorption on the surface of sorbent could have taken an important role in sorbing Chromium and exchange mechanism might have reduced.

Further, the effect of temperature is significant on pyrolysed type of adsorbent suggests that the biosorption between chromium and pyrolysed tamarind adsorbent involve the combination of chemical interaction and physical adsorption. With the increase in temperature the pores in the adsorbent enlarges resulting in getting more surface area available for diffusion and adsorption. [43]

\subsection{Response Surface Methodology (RSM)}

Regression analysis was done to fit the response function as per the equation 1 and the results are reported as eq.2, eq. 3 and eq. 4 for T, TCP, TPP, respectively

$$
\begin{aligned}
& Y=92.9229-3.3183 X_{1}-13.3267 X_{2}+5.4933 X_{3}+5.6333 X_{4}- \\
& +1537 X_{1}{ }^{2}-19.6637 X_{2}{ }^{2}+0.70639 X_{3}{ }^{2}-3.0737 X_{4}{ }^{2} \\
& +4.0000 X_{1} X_{2}-0.8400 X_{1} X_{3}-14.2250 X_{2} X_{3}+7.5050 X_{2} X_{4} \\
& +3.0650 X_{3} X_{4} \ldots \ldots \ldots \ldots \ldots . . .(2)
\end{aligned}
$$

$Y=75.68-0.84 X_{1}-4.7 X_{2}+11.9467 X_{3}+2.2983 X_{4}+1.0242 X_{1}^{2}-$ $15.4858 X_{2}^{2}-0.2308 X_{3}^{2}+10.9492 X_{4}^{2}-10.825 X_{1} X_{2}-$ $10.19 X_{1} X_{3}+4.3450 X_{1} X_{4}+17.94 X_{2} X_{3}-0.715 X_{2} X_{4}$ $+7.4 \mathrm{X}_{3} \mathrm{X}_{4} \cdots \cdots(3)$

$$
\begin{aligned}
& Y=70.38-1.36 X_{1}-4.9883 X_{2+}+11.7750 X_{3}+1.8783 X_{4} \\
& +1.1200 X_{1}{ }^{2}-14.5850 X_{2}{ }^{2}-0.4850 X_{3}+10.8500 X_{4}{ }^{2}- \\
& 10.3600 X_{1} X_{2}-7.5600 X_{1} X_{3}+5.5650 X_{1} X_{4} \\
& +16.78 X_{2} X_{3}+0.2950 X_{2} X_{4}+8.9550 X_{3} X_{4} \ldots . . . . . .(4)
\end{aligned}
$$


These above equations explain the effect of individual variable (linear and squared) and interactive effects on Chromium adsorption onto different adsorbent. The chromium removal was predicted using eq. 2 - eq.4 at experimental parameters and the obtained values are also reported in Table 2.

Multiple regression coefficient $\mathrm{R}^{2}$ is calculated from the second degree polynomial equation (equation 2,3 and 4), is $\mathrm{R}^{2}=0.8612$ for $\mathrm{T}, 0.7995$ for TCP and 0.7561 for TPP indicates that the predicted values are closer to experimental data as shown in Table 2. For a good statistical model, $\mathrm{R}^{2}$ value should be closer to 1 , and a value of 0.75 indicates aptness of the model. The $\mathrm{R}^{2}$ value of 0.8612 for $\mathrm{T}$ implies that more than $86.12 \%$ of experimental data was compatible with the model and only less than $13.88 \%$ of the variations are not explained by the model [44].

The experimental results were analysed and student ' $t$ ' test was conducted to find the significance of individual parameters, squared parameters and interactive parameters combination, smaller the probability value more significant is the effect. The regression coefficients, ' $t$ ' test results an $\mathrm{ld}$ probability values are reported in Table 3 . The results show that $\mathrm{pH}$ and square effect of $\mathrm{pH}$ is significant for crude tamarind (probability value, $\mathrm{p}=0.000$ ) whereas temperature becomes significant for complete and partial pyrolysed tamarind.

Table 2. Central Composite Design Matrix of design specifications along with observed response for chromium removal by T,

\begin{tabular}{|c|c|c|c|c|c|c|c|c|c|c|}
\hline \multirow{3}{*}{$\begin{array}{l}\text { Run } \\
\text { Order }\end{array}$} & \multirow{3}{*}{$\begin{array}{l}\text { Conce } \\
\text { ntrati } \\
\text { on }\end{array}$} & \multirow[t]{3}{*}{ pH } & \multirow{3}{*}{$\begin{array}{l}\text { Tem } \\
\text { pera } \\
\text { ture }\end{array}$} & \multirow{3}{*}{$\begin{array}{l}\text { Bioma } \\
\text { ss } \\
\text { loadin } \\
\text { g }\end{array}$} & \multicolumn{6}{|c|}{ \% Chromium removal } \\
\hline & & & & & \multicolumn{2}{|c|}{$\mathbf{T}$} & \multicolumn{2}{|l|}{ TCP } & \multicolumn{2}{|l|}{ TPP } \\
\hline & & & & & $\begin{array}{l}\text { Theoretic } \\
\text { al }\end{array}$ & $\begin{array}{l}\text { Experime } \\
\text { ntal }\end{array}$ & $\begin{array}{l}\text { Theoretic } \\
\text { al }\end{array}$ & $\begin{array}{l}\text { Experiment } \\
\text { al }\end{array}$ & $\begin{array}{l}\text { Theoretic } \\
\text { al }\end{array}$ & $\begin{array}{l}\text { Experimenta } \\
1\end{array}$ \\
\hline 1 & 125 & 4 & 40 & 5.5 & 89.32 & 88.67 & 75.68 & 70.18 & 70.38 & 68.83 \\
\hline 2 & 87.5 & 5.5 & 35 & 3.25 & 69.68 & 66.88 & 70.62 & 65.74 & 67.53 & 65.87 \\
\hline 3 & 162.5 & 2.5 & 45 & 7.75 & 92.19 & 94.34 & 86.8 & 81.12 & 82.09 & 78.43 \\
\hline 4 & 162.5 & 2.5 & 45 & 3.25 & 83.59 & 85.43 & 89.21 & 85.48 & 84.77 & 86.27 \\
\hline 5 & 50 & 4 & 40 & 5.5 & 91.85 & 88.89 & 71.18 & 67.89 & 66.68 & 67.23 \\
\hline 6 & 87.5 & 2.5 & 45 & 3.25 & 89.70 & 92.34 & 86.78 & 79.15 & 81.23 & 76.78 \\
\hline 7 & 162.5 & 5.5 & 45 & 7.75 & 90.36 & 90.90 & 78.39 & 72.23 & 73.4 & 70.23 \\
\hline 8 & 87.5 & 2.5 & 35 & 3.25 & 88.98 & 87.78 & 83.36 & 77.36 & 81.02 & 75.67 \\
\hline 9 & 162.5 & 2.5 & 35 & 3.25 & 89.51 & 88.11 & 84.59 & 80.55 & 79.08 & 77.87 \\
\hline 10 & 87.5 & 5.5 & 35 & 7.75 & 85.74 & 86.01 & 53.68 & 52.45 & 48.71 & 50.23 \\
\hline 11 & 125 & 4 & 40 & 10 & 90.60 & 89.14 & 90.83 & 86.89 & 85.23 & 81.43 \\
\hline 12 & 87.5 & 5.5 & 45 & 7.75 & 89.21 & 87.45 & 89.91 & 91.23 & 89.61 & 86.56 \\
\hline 13 & 125 & 4 & 40 & 5.5 & 89.44 & 90.88 & 75.68 & 77.03 & 70.38 & 72.34 \\
\hline 14 & 125 & 4 & 30 & 5.5 & 90.36 & 91.45 & 56.58 & 53.28 & 50.75 & 51.11 \\
\hline 15 & 87.5 & 2.5 & 35 & 7.75 & 87.93 & 88.56 & 72.2 & 75.35 & 66.32 & 64.34 \\
\hline 16 & 125 & 4 & 40 & 1 & 83.34 & 82.17 & 63.79 & 66.56 & 58.57 & 56.72 \\
\hline 17 & 125 & 4 & 40 & 5.5 & 88.34 & 86.36 & 75.68 & 71.72 & 70.38 & 67.66 \\
\hline 18 & 125 & 4 & 40 & 5.5 & 90.34 & 89.90 & 75.68 & 79.58 & 70.38 & 72.45 \\
\hline 19 & 200 & 4 & 40 & 5.5 & 82.93 & 83.49 & 63.59 & 60.14 & 57.66 & 57.78 \\
\hline 20 & 162.5 & 5.5 & 35 & 7.75 & 81.45 & 80.79 & 61.89 & 63.33 & 56.93 & 54.21 \\
\hline 21 & 125 & 1 & 40 & 5.5 & 97.08 & 97.27 & 44.56 & 46.80 & 40.4 & 43.45 \\
\hline 22 & 87.5 & 2.5 & 45 & 7.75 & 94.93 & 96.90 & 83.59 & 80.90 & 78.75 & 74.56 \\
\hline 23 & 125 & 4 & 40 & 5.5 & 89.34 & 88.15 & 75.68 & 73.51 & 70.38 & 67.67 \\
\hline 24 & 125 & 4 & 40 & 5.5 & 88.34 & 87.89 & 75.68 & 74.72 & 70.38 & 67.56 \\
\hline 25 & 125 & 4 & 50 & 5.5 & 90.14 & 89.18 & 75.68 & 73.35 & 70.38 & 65.79 \\
\hline 26 & 125 & 7 & 40 & 5.5 & 45.68 & 47.79 & 57.19 & 58.11 & 52.53 & 55.65 \\
\hline 27 & 162.5 & 2.5 & 35 & 7.75 & 89.26 & 91.90 & 89.53 & 84.93 & 82.96 & 78.89 \\
\hline 28 & 162.5 & 5.5 & 35 & 3.25 & 71.80 & 73.76 & 66.78 & 68.84 & 60.59 & 58.75 \\
\hline 29 & 162.5 & 5.5 & 45 & 3.25 & 88.38 & 87.68 & 80.59 & 77.57 & 75.2 & 73.21 \\
\hline 30 & 125 & 4 & 40 & 5.5 & 87.34 & 88.68 & 75.68 & 73.57 & 70.38 & 66.74 \\
\hline 31 & 87.5 & 5.5 & 45 & 3.25 & 86.35 & 84.48 & 86.55 & 84.46 & 80.13 & 79.12 \\
\hline
\end{tabular}




\subsection{Analysis of Variance (ANOVA)}

The results of multiple linear regressions conducted for the second order response surface model by ANOVA are given in Table 4.The Fischer's variance ratio, $\mathrm{F}$ value $=\left(\mathrm{Sr}^{2} / \mathrm{Se}^{2}\right)$, is the ratio of mean square owing to regression to the mean square owing to the error. The higher the F-value and lower the probability $\mathrm{P}$ value $(<0.01)$ demonstrates significance for the regression model. From Table 4 it is seen that linear effect was significant in all cases and square effect is also significant in the case of Crude tamarind

Table 3. Student " $t$ " test analysis for bio sorption of chromium by T, TCP \& TPP

\begin{tabular}{|c|c|c|c|c|c|c|c|c|c|}
\hline \multirow{2}{*}{ Term } & \multicolumn{3}{|c|}{ Regression Coefficient } & \multicolumn{3}{|l|}{$\mathrm{t}$} & \multicolumn{3}{|l|}{$\mathrm{P}$} \\
\hline & $\mathbf{T}$ & TCP & TPP & $\mathbf{T}$ & TCP & TPP & $\mathbf{T}$ & TCP & TPP \\
\hline Constant & 92.9229 & 75.6800 & 70.38 & 35.12 & 17.877 & 16.817 & 0.000 & 0.000 & 0.000 \\
\hline Concentration & -3.3183 & -0.8400 & -1.36 & -1.161 & -0.184 & -0.172 & 0.263 & 0.857 & 0.809 \\
\hline $\mathrm{pH}$ & -13.3267 & -4.7000 & -4.988 & -4.664 & -1.028 & -1.003 & 0.000 & 0.319 & 0.287 \\
\hline Temperature & 5.4933 & 11.9467 & 11.775 & 1.922 & 2.613 & 2.243 & 0.073 & 0.019 & 0.012 \\
\hline Biomass loading & 5.6333 & 2.2983 & 1.878 & 1.971 & 0.503 & 0.479 & 0.066 & 0.622 & 0.601 \\
\hline $\begin{array}{l}\text { Concentration*Co } \\
\text { ncentration }\end{array}$ & -1.1537 & 1.0242 & 1.120 & -0.220 & 0.122 & 0.106 & 0.828 & 0.904 & 0.839 \\
\hline $\mathrm{pH} * \mathrm{pH}$ & -19.6637 & -15.4858 & -14.585 & -3.756 & -1.848 & -1.583 & 0.002 & 0.083 & 0.074 \\
\hline $\begin{array}{l}\text { Temperature*Tem } \\
\text { perature }\end{array}$ & 0.7063 & -0.2308 & -0.485 & 0.135 & -0.028 & -0.016 & 0.894 & 0.078 & 0.069 \\
\hline $\begin{array}{l}\text { Biomass } \\
\text { loading*Biomass } \\
\text { loading }\end{array}$ & -3.0737 & 10.9492 & 10.850 & -0.587 & 1.307 & 1.156 & 0.565 & 0.210 & 0.182 \\
\hline Concentration*pH & 4.0000 & -10.8250 & 10.360 & 0.571 & -0.966 & -0.856 & 0.576 & 0.348 & 0.313 \\
\hline $\begin{array}{l}\text { Concentration*Te } \\
\text { mperature }\end{array}$ & -0.8400 & -10.1900 & -7.560 & -0.120 & -0.910 & -0.789 & 0.906 & 0.376 & 0.324 \\
\hline $\begin{array}{l}\text { Concentration*Bio } \\
\text { mass loading }\end{array}$ & -1.2800 & 4.3450 & 5.565 & -0.183 & 0.388 & 0.318 & 0.857 & 0.703 & 0.678 \\
\hline pH*Temperature & 14.2250 & 17.9400 & 16.78 & 2.032 & 1.602 & 1.497 & 0.059 & 0.129 & 0.111 \\
\hline $\begin{array}{l}\text { pH*Biomass } \\
\text { loading }\end{array}$ & 7.5050 & -0.7150 & 0.295 & 1.072 & -0.064 & -0.057 & 0.300 & 0.950 & 0.889 \\
\hline $\begin{array}{l}\text { Temperature*Bio } \\
\text { mass loading }\end{array}$ & 3.0650 & 7.4000 & 8.955 & 0.438 & 0.661 & 0.564 & 0.667 & 0.518 & 0.473 \\
\hline
\end{tabular}

Table 4. Analysis of Variance (ANOVA) for the selected quadratic model for the removal of Chromium by T, TCP \& TPP

\begin{tabular}{|l|l|l|l|l|l|l|l|l|l|l|l|l|}
\hline Source & DF & \multicolumn{1}{l|}{ Sum of squares } & F & \multicolumn{2}{l|}{ Prob>F } \\
\hline & T & TCP & TPP & T & TCP & TPP & T & TCP & TPP & T & TCP & TPP \\
\hline Regression & 14 & 14 & 14 & 2498.73 & 2361.15 & 2359.62 & 3.64 & 1.34 & 1.32 & 0.008 & 0.283 & 0.276 \\
\hline Linear & 4 & 4 & 4 & 1503.14 & 1024.80 & 1020.37 & 7.67 & 2.04 & 2.01 & 0.001 & 0.13 & 0.11 \\
\hline Square & 4 & 4 & 4 & 709.18 & 719.33 & 715.56 & 3.62 & 1.43 & 1.38 & 0.028 & 0.268 & 0.259 \\
\hline Interaction & 6 & 6 & 6 & 286.41 & 617.01 & 612.96 & 0.97 & 0.82 & 0.80 & 0.473 & 0.571 & 0.566 \\
\hline $\begin{array}{l}\text { Residual } \\
\text { Error }\end{array}$ & 16 & 16 & 16 & 783.91 & 2007.27 & 2006.18 & & & & & & \\
\hline Total & 30 & 30 & 30 & 3282.64 & 4368.42 & 4364.44 & & & & & & \\
\hline
\end{tabular}

\subsection{Optimization of Response}

The optimization of process variables are done to get maximum \% removal using response optimizer in Minitab 16. In this regard second degree polynomial equations (eq.2, eq. 3 and eq.4) were used to get the optimum values for the variables. Table 5 gives the optimum values for all adsorbents. Maximum removal of $96.09 \%$ chromium was achieved with crude tamarind at initial concentration
$(71.7213 \mathrm{mg} / \mathrm{l})$, with least biomass $(4.59 \mathrm{~g} / 100 \mathrm{ml})$ and at lower temperature $\left(41.82^{\circ} \mathrm{C}\right)$ in acidic medium $(\mathrm{pH} 2.47)$. 
Table 5. Optimized parameters for T, TCP and TPP

\begin{tabular}{|l|l|l|l|l|l|l|}
\hline Biosorbent & $\begin{array}{l}\text { Initial metal } \\
\text { ion } \\
\text { Concentration } \\
(\mathbf{p p m})\end{array}$ & $\mathbf{p H}$ & $\begin{array}{l}\text { Temperature } \\
(\mathbf{0} \mathbf{C})\end{array}$ & $\begin{array}{l}\text { Biomass } \\
\text { Load }(\mathbf{g} / \mathbf{l})\end{array}$ & $\begin{array}{l}\text { Predicted } \\
\text { \% } \\
\text { Chromium } \\
\text { Removal }\end{array}$ & $\begin{array}{l}\text { Experimental } \\
\text { \% } \\
\text { Chromium } \\
\text { Removal }\end{array}$ \\
\hline T & 71.7213 & 2.47 & 41.82 & 4.59 & 96.86 & 96.09 \\
\hline TCP & 79.9180 & 2.961 & 48.56 & 9.0246 & 91.08 & 90.36 \\
\hline TPP & 95.0350 & 2.259 & 48.8364 & 9.8701 & 88.19 & 86.56 \\
\hline
\end{tabular}

\section{CONCLUSIONS}

In the present work biosorption of chromium was studied in batch experiments using three types of biosorbent derived from tamarind fruit shell. Central composite design was adopted to study of effect of variation in parameters like initial chromium concentration, $\mathrm{pH}$, temperature and adsorbent dosage. For all the adsorbents, it is observed from the student " $\mathrm{t}$ " test that for non- pyrolysed type of adsorbents, $\mathrm{pH}$ was significant and the temperature becomes significant for pyrolysed samples. ANOVA analysis reveals that for all the adsorbents linear effect was significant and for crude tamarind square effect is also significant. Analysis of variance also showed that a reasonably high regression coefficient of 0.8612 , ensuring a satisfactory adjustment of the second order regression model with the experimental data.

The optimization of process variables indicates that crude tamarind removed maximum chromium of $96.09 \%$ with initial metal concentration of $71.7213 \mathrm{mg} / \mathrm{l}, \mathrm{pH}$ of 2.47 , temperature of $41.82{ }^{\circ} \mathrm{C}$ and lowest biomass loading of 4.59 $\mathrm{g} / 100 \mathrm{ml}$. The study clearly demonstrating the use of crude tamarind pod shell which is abundant and available at throw away price may be used to treat a chemical waste containing chromium.

\section{NOMENCLATURE}

T-Tamarind crude

TCP-Tamarind crude completely pyrolysed

TPP- Tamarind crude partially pyrolysed

\section{REFERENCES}

[1]. "Chromium, Environmental Health Criteria 61", World Health Organization, WHO, Geneva,(1988).

[2]. Saner. G, "Chromium in Nutrition and Disease", Alan R Liss Inc., New York, (1980).

[3]. "Toxicological Profile for Chromium", Public Health Services Agency for Toxic Substances and Diseases Registry,US.Department of Health and Human Services, Washington,DC, (1991).

[4]. Cieslak-Golonka.M, "Toxic and mutagenic effects of chromium (VI)", Polyhedron, 15(1995), 3667-3689.

[5]. Raji.C, Anirudhan. T.S, "Batch Cr (VI) removal by polyacrylamide-grafted sawdust Kinetics and Thermodynamics",Water Res., 32, (1998), 3772-3780.

[6]. Udy. M.J, "Chromium", Reinhold Publishing Corporation, New York, (1956).
[7]. Casarett. L.J,and Doul. J., Toxicology, the basic science of poisons, Macmillan, New York, (1980).

[8]. Nriagu. J.O, and Nieboer. E., Chromium in the Natural and Human Environment, Wiley, New York, (1988).

[9]. Environmental Pollution Control Alternatives. Environmental Protection Agency,EPA/625/5-90/025, EPA/625/4-89/023, Cincinnati, US, (1990).

[10]. Drinking water-specification (first revision), Indian Standard, IS 10500, (1991).

[11]. Zhou. X, Korenaga. T, Takahashi. T, Moriwake. T, and Shinoda.S.,"A process monitoring/controlling system for the treatment of wastewater containing chromium(VI)", WaterRes., 27, (1993), 1049-1054.

[12]. Tiravanti. G, Petruzzelli. D, and Passiono. R., "Pretreatment of tannery wastewaters by an ion exchange process for $\mathrm{Cr}$ (III) removal and recovery", Water Sci. Technol., 36, (1997) ,197-207.

[13]. Kongsricharoern. N, Polprasert. C., "Chromium removal by a bipolar electrochemical Precipitation process", Water Sci. Technol., 34, (1996), 109-116.

[14]. Seaman .J.C, Bertsch.P.M,and Schwallie. L., "In situ $\mathrm{Cr}(\mathrm{VI})$ reduction within coarse-textured,oxide-coated soil and aquifer systems using Fe(II) solutions", Environ. Sci.Technol., 33, (1999),938-944.

[15]. Calace.N, Muro.D.A, Nardi. E, Petronio. B.M, and Pietroletti.M., "Adsorption isotherms for describing heavy metal retention in paper mill sludges", Ind. Eng. Chem. Res., 41, (2002), 5491-5497.

[16]. Pagilla.K, Canter. L.W., "Laboratory studies on remediation of chromium contaminated Soils", J. Environ. Eng., 125, (1999), 243-248.

[17]. Chakravarti. A.K, Chowdhury. S.B, Chakrabarty. S, Chakrabarty. T, and Mukherjee. D.C.,"Liquid membrane multiple emulsion process of chromium (VI) separation from waste Waters",Colloids Surf. A. Physicochem. Eng. Aspects, 103, (1995), 59-71.

[18]. Lin.C.F, Rou. W, and Lo. K.S., "Treatment strategy for Cr(VI) bearing wastes", Water Sci.Technol., 26, (1992), 2301-2304.

[19]. Aksu. Z, and Kutsal.T. A., "Comparative study for biosorption characteristics of heavy metal Ions with C. vulgaris", Environ. Technol., 11, (1990) ,979-987.

[20]. Aksu. Z, Ozer.D, Ekiz. H, Kutsal.T, and Calar.A.," Investigation of biosorption of chromium(VI) on C. crispate in two staged batch reactor", Environ. Technol., 17, (1996) ,215-220.

[21]. Bailey. S.E, Olin.T.J, Bricka,R.M, and Adrian. D.D., "A review of potentially low cost Sorbents for heavy metals”, Water Res., 33, (1999), 2469-2479. 
[22]. Weng. C.H, Haung. C.P, Allen. H.E, and Sanders. P.F., " $\mathrm{Cr}(\mathrm{VI})$ adsorption onto hydrous concrete particles from groundwater", J. Environ. Eng., 127, (2001), 1124-1131.

[23]. Kratochvil.D. P, Pimentel, and Volesky. B., "Removal of trivalent and hexavalent chromium by seaweed biosorbent", Environ. Sci. Technol., 32, (1998), 2693-2698. [24]. Reddad. Z, Gerente. C, Andres. Y, and Cloirec. P., "Adsorption of several metal ions onto a low cost biosorbent: kinetic and equilibrium studies", Environ. Sci. Technol., 36, (2002),2067-2073.

[25]. Dupond. L, and Guillon. E, "Removal of Hexavalent chromium with a lingo cellulosic substrate extracted from wheat bran", Environ. Sci. Technol., 37, (2003), 4235-4241. [26]. Periasamy. K, Srinivasan. K, and Muruganan. P.R., "Studies on chromium(VI) removal by activated ground nut husk carbon", Indian J. Environ. Health, 33, (1991), 433439.

[27]. Tan. W.T, Ooi. S.T, and Lee. C.K., "Removal of $\mathrm{Cr}(\mathrm{VI})$ from solution by coconut husk and Palm pressed fibres", Environ. Technol., 14 ,(1993), 277-282.

[28]. Selomulya. C, Meeyoo. V, and Amal. R., "Mechanisms of $\mathrm{Cr}(\mathrm{VI})$ removal from water by various types of activated carbons", J. Chem. Technol. Biotechnol., 74, (1994), 111-122.

[29]. Selvi, K, Pattabhi. S, and Kadirvelu. K., "Removal of $\mathrm{Cr}(\mathrm{VI})$ from aqueous solution by adsorption onto activated carbon", Bioresour. Technol., 80, (2001), 87-89.

[30]. Hamadi. N.K, Chen. X.D, Farid. M.M, and Lu. M.G.Q., "Adsorption kinetics for the removal of chromium(VI) from aqueous solution by adsorbents derived from used tyres and sawdust", J.Chem. Eng., 84, (2001), 95-105.

[31]. Dakiky. M, Khamis. M, Manassra. M, and Mer'eb M., "Selective adsorption of chromium(VI) inindustrial waste water using low cost abundantly available adsorbents",Adv. Environ. Res., 6, (2002), 533-540.

[32]. Low. K.S, Lee. C.K, and NG. A.Y., "Column study on the sorption of $\mathrm{Cr}(\mathrm{VI})$ using quaternized rice hulls", Bioresour. Technol., 68, (1999), 205-208.

[33]. Cimino.G, Passerini. A, and Toscano G., "Removal of toxic cations and $\mathrm{Cr}(\mathrm{VI})$ from qqueous solution by hazelnut shell”, Water Res., 34, (2000), 2955-2962.

[34]. Kobya. M., "Adsorption, kinetic and equilibrium studies of $\mathrm{Cr}(\mathrm{VI})$ by hazelnut shell activated carbon", Adsorpt. Sci. Technol., 22, (2004) ,51-64.

[35]. Candela. M.P, Candela, J.M.M, Martinez, and Macia. R.T., "Chromium(VI) removal with activated carbons", Water Res., 29, (1995), 2174-2180.

[36]. Bosinco. S, Roussy. J, Guibal. E.P, and Cloirec. L.E., "Interaction mechanisms between hexavalent chromium and corncob", Enviro. Technol., 17, (1996), 55-62.

[37]. Das. D.D, Mahapatra. R, Pradhan.J, Das.S.N, and Thakur, R.S., "Removal of $\mathrm{Cr}(\mathrm{VI})$ fromaqueous solution using activated cow dung carbon", J. Colloid Interface Sci., 232, (2000) 235-240.

[38]. Ravikumar.K, Pakshirajan.K, Swaminathan.T, Balu.K., "Optimization of batch process parameters using response surface methodology for dye removal by a novel adsorbent”.Chem.Eng.J.,105,(2005),131-138.
[39]. Korbathi.B.K., "Response surface optimeization of electrochemical treatment of textile

dye wastewater".J.Hazard.Mater.,145,(2007),277-286.

[40]. Aleboyeh.A, Daneshvar,N, and asiri.M.B.," Optimization of C.I.Acid Red 14 azo dye removal by electrocoagulation batch process with response surface methodology". Chem.Eng.Process.,47,(2008),827-832

[41]. APHA, AWWA and WPCF, Standard methods for the examination of water and waste water, Washington D. C., vol. 19, 1995.

[42]. Hala. Y.E,and Eman. M.E., "Optimization of Batch Process Parameters by Response Surface Methodology for Mico remediation of Chrome-VI by a Chromium Resistant Strain of Marine TrichodermaViride”, American-Eurasian Journal of Agriculture \& Environmental Science, Vol. 5, (5), (2009), 676 - 681.

[43]. Saleem.M,Pirzada.T, and Qadeer.R. "Sorption of acid violet 17 and direct red 80 dyes on cotton fibre from aqueous solution Collides Surf.A”, Physicochem Engg.Asp., 292,(2007),246-250

[44]. Rajasimman.M and Murugaiyan.K," Optimization of process variables for the biosorption of chromium using Hypnea valentiae",Nova biotechnological,10-2,(2010),107115

\section{BIOGRAPHIES}

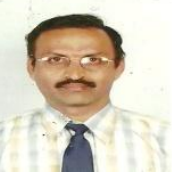

Sudhanva M Desai. is a Associate Professor at Department of Chemical Engineering, DSCE Bangalore. He obtained bachelor degree in Chemical Engineering with III rank to the Karnataka University Dharwad, India in 1988. Completed M.Tech in General Chemical Engineering from Bangalore University in 1998. Major research areas include Biosorption of Heavy metals He has 18 years of teaching and 6 years industrial experience. He has Two International journal publications and 3 International conference publications. He has guided many UG and PG projects few were awarded at various competitions.

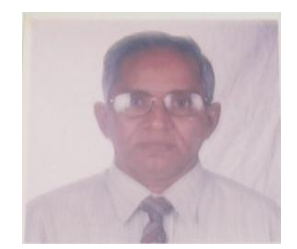

N.C.L.N.Charyulu, graduated from Andhra Uniiversity in Chem. Engg.with $3^{\text {rd }}$ rank in the year 1963. M.Tech. from I.I.T. Kharagpur and Ph.D. from I.I.Sc., Bangalore. Worked for 33 years in KREC (Karnataka Regional Engineering College), Surathkal, Mangalore, Karnataka, INDIA and 10 years in CBIT Hyderabad, India. Guided 4 Ph.Ds. Specialisation is Bioconversion, biosynthesis, bioremediation and chemical reaction engineering. Published 15 national and international publications coauthored for two book

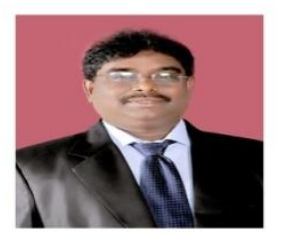

Dr. Suggala.V.Satyanarayana, is a Professor at Department of Chemical Engineering, JNTUA College of Engineering, Anantapuramu. $\mathrm{He}$ obtained his B.Tech degree from Osmania University Hyderabad and M. Tech \& PhD from IIT Kanpur. He has 20 years of 
teaching experience at JNTUA College of Engineering Anantapuramu and 2.5 years of Research Experience at IICT, Hyderabad. He received the Best Teacher Award for the year 2013 by the Government of Andhra Pradesh. Major research areas include pervaporation, gas separation, adsorption and multi-objective optimization Guided 4 PhDs and published 53 research papers. Successfully completed 6 Consultancy \& Sponsored Projects and co-authored one book.

Dr. Suggala.V.Satyanarayana is the corrosponding author of this paper. Email: svsatya7@gmail.com, 09849509167. 